Article

\title{
Removal of Antibiotic Resistance Genes at Two Conventional Wastewater Treatment Plants of Louisiana, USA
}

\author{
Ocean Thakali ${ }^{1}{ }^{\circledR}$, John P. Brooks ${ }^{2}{ }^{\circledR}$, Shalina Shahin ${ }^{3}$, Samendra P. Sherchan ${ }^{3}$ \\ and Eiji Haramoto $4, * \mathbb{D}$ \\ 1 Environment and Social System Science Course, University of Yamanashi, 4-3-11 Takeda, Kofu, \\ Yamanashi 400-8511, Japan; othakali@gmail.com \\ 2 Genetics and Sustainable Agricultural Unit, Agricultural Research Service, U.S. Department of Agriculture, \\ 810 Highway 12 East, Mississippi State, MS 39762, USA; john.brooks@usda.gov \\ 3 Department of Global Environmental Health Sciences, Tulane University, 1440 Canal Street, Suite 2100, \\ New Orleans, LA 70112, USA; sshahin@tulane.edu (S.S.); sshercha@tulane.edu (S.P.S.) \\ 4 Interdisciplinary Center for River Basin Environment, University of Yamanashi, 4-3-11 Takeda, Kofu, \\ Yamanashi 400-8511, Japan \\ * Correspondence: eharamoto@yamanashi.ac.jp; Tel.: +81-55-220-8725
}

Received: 27 May 2020; Accepted: 15 June 2020; Published: 17 June 2020

\begin{abstract}
Wastewater treatment plants (WWTPs) represent all known types of antibiotic resistance mechanisms and are considered as the critical points for the spread of antibiotic resistance genes (ARGs). The purpose of this study is to investigate the removal of a Class 1 integrase gene (intI1) and a selected set of ARGs ( $b l a_{\mathrm{TEM}}, e r m F$, mec $A$, and tet $\left.A\right)$ at two conventional WWTPs by using chlorination in Louisiana, USA. We collected 69 wastewater samples (23 each from influent, secondary effluent, and final effluent) and determined the concentrations of ARGs by using quantitative polymerase chain reaction. All tested ARGs, except for mecA, were detected in 83-96\% and 30-65\% of influent and final effluent samples, respectively. Although the ARGs underwent approximately $3-\log _{10}$ reduction, two WWTPs on an average still released $3.3 \pm 1.7 \log _{10}$ copies/mL of total ARGs studied in the effluents. Chlorination was found to be critical in the significant reduction of total ARGs $(p<0.05)$. Correlation analysis and the ability of intI1 to persist through the treatment processes recommend the use of intI1 as a marker of ARGs in effluents to monitor the spread of antibiotic resistance in effluents. Our study suggests that conventional WWTPs using chlorination do not favor the proliferation of antibiotic resistance bacteria and ARGs during wastewater treatment.
\end{abstract}

Keywords: antibiotic resistance gene; chlorination; intI1; quantitative PCR; reduction; wastewater treatment

\section{Introduction}

Despite the presence of bacteria that harbor antibiotic resistance genes (ARGs) in a pristine environment [1], studies have reported that an increase in ARGs is related to anthropogenic activities, such as discharge of feces in sewage and untreated wastewater [2,3]. The spread of such bacteria and ARGs has led to antibiotic resistance becoming a major public health issue [4]. Wastewater treatment plants (WWTPs) are at the forefront in limiting the effects of such anthropogenic activities in water. Apart from organic compounds, wastewater also collects fecal residues, which include bacteriophages, antibiotic resistance bacteria (ARB) along with their ARGs, metals, nutrients, and antibiotic residues. Therefore, WWTPs can provide environmental conditions potentially favoring the persistence of ARGs and are considered "hotspots" [5] or "critical points" [6] for the spread of ARGs in the environment. 
The last decade has witnessed a large number of studies on the removal of ARGs at WWTPs by using different systems [7-10]. However, most of the studies were conducted by using different ARGs as the diversity of ARGs varies between countries, and different ARGs have displayed different removal rates [11]. The removal of ARB and ARGs has also been reported to be affected by the type of technology used; however, there is a lack of a specific treatment plan, and more studies are needed to understand the transmission of ARGs in all treatment processes [12]. Furthermore, some studies have reported inconsistent results that showed an increase in the abundance of certain ARGs in effluents as compared to the influents of WWTPs [13]. Because of water scarcity in many cities, the reuse of reclaimed water for potable use and irrigation is also practiced [14]. The effluent of WWTPs is drained into aquatic bodies, which often act as a source of drinking water for people living further downstream. Given the potential risk of spread of antibiotic resistance and the lack of guidelines for the use of water contaminated with ARB and ARGs, the reduction of such contaminants at WWTPs deserves special attention [15].

The purpose of this study is to investigate the incidence and reduction of four clinically relevant ARGs (bla $a_{\mathrm{TEM}}, \operatorname{ermF}, \operatorname{mec} A$, and tet $A$ ) and a Class 1 integrase gene (intI1) at two WWTPs (Plants A and B) by incorporating biological treatment with chlorination in Louisiana, USA. The four chosen ARGs were Class A $B$ lactamase (bla $\left.a_{\mathrm{TEM}}\right)$, erythromycin resistance gene $(\mathrm{ermF})$, methicillin resistance gene $(m e c A)$, and tetracycline resistance gene $(\operatorname{tet} A)$. These genes represent resistant mechanisms to the different classes of commonly used antibiotics $[16,17]$. Integrons can acquire genes to spread antibiotic resistance [18] and has been proposed as an indicator of antibiotic resistance in the environment [19]. In addition, this study also evaluated the suitability of a class one integron (intI1) as an indicator of antibiotic resistance in wastewater.

\section{Materials and Methods}

\subsection{Collection of Wastewater Samples}

We collected influent, secondary effluent, and final effluent ( $\mathrm{n}=23$ each) samples monthly over a one-year period between March 2017 and February 2018, except for June 2017, at Plant A and between November 2016 and October 2017 at Plant B. Details of Plant A and collected samples have been described previously in a study [20]. Plant B, which is another conventional treatment system draining into the Mississippi River (Figure 1), treats approx. 60,000 $\mathrm{m}^{3} /$ day. Both WWTPs performed disinfection with chlorination as shown in Figure 1.

\section{Plant A}

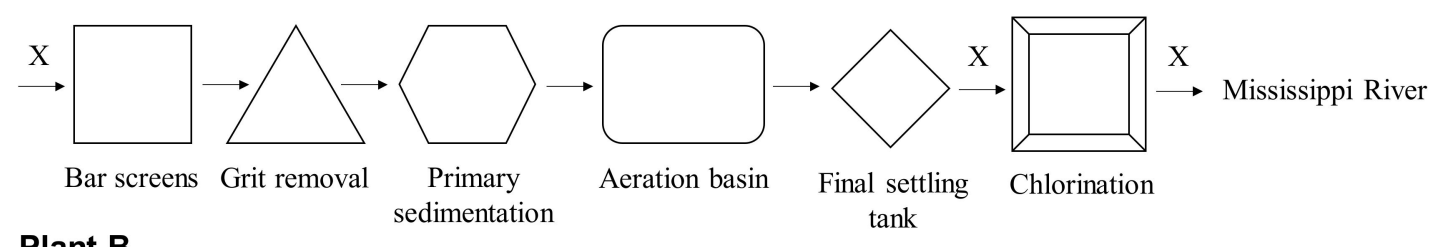

\section{Plant B}

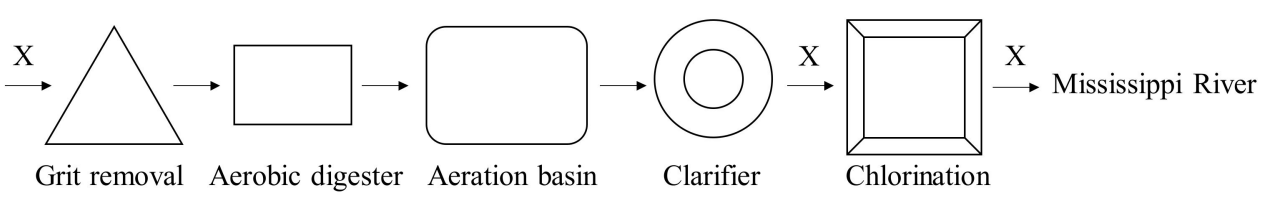

Figure 1. Schematic layout of the WWTPs. Letter " $X$ " represents the sampling points.

\subsection{Water Quality Parameters}

We analyzed biological oxygen demand (BOD) and total suspended solids (TSS) in Plant A, and microbiological indicators of fecal contamination (total coliforms and Escherichia coli) in Plant B by using the standard method for the examination of wastewater [21]. 


\subsection{Bacterial DNA Extraction}

We concentrated bacteria in the wastewater samples by filtering $(100 \mathrm{~mL}$ for influent and $1000 \mathrm{~mL}$ for secondary and final effluent) them through a $0.22-\mu \mathrm{m}$ pore size membrane (diameter, $90 \mathrm{~mm}$; Millipore, Bedford, MA, USA). Thereafter, we extracted bacterial DNA from the filter by using a PowerSoil DNA Isolation Kit (QIAGEN, Hilden, Germany) according to the manufacturer's instructions.

\subsection{Quantitative Polymerase Chain Reaction ( $q P C R$ )}

We analyzed the extracted bacterial DNA for the selected set of ARGs (tetA, bla $a_{\mathrm{TEM}}$, ermF, and mecA), intI1, and 16S rRNA of total bacteria by using a StepOne Plus Real-Time PCR System (Applied Biosystems, Foster City, CA, USA) and Power SYBR Green PCR Master Mix (Applied Biosystems). We followed forward and reverse primers and thermal cycling conditions as mentioned in previous research works [18,22-26]. We included DNA extracted from environmental or clinical isolates and PCR-grade water as positive and negative controls, respectively. Inhibition control comprised of random DNA samples spiked with quantified positive control DNA. Deviation of more than 1 cycle from expected cycle threshold value suggested the presence of qPCR inhibitors in DNA samples, and the DNA samples were subjected to 10-fold dilution. Additionally, we conducted all assays in duplicate, and subjected amplification products to melting-curve analysis and quantified them by using a six-point tenfold standard curve. For all standard curves, the linear coefficients $\left(r^{2}\right)$ were $\geq 0.98$. Limit of detection (LOD) of an assay was calculated as the lowest concentration of the standard plasmid DNA that was amplified. LOD values were 5 copies $/ \mathrm{mL}$ for $t e t A$ and 50 copies $/ \mathrm{mL}$ for other ARGs and intI1.

\subsection{Data Analysis}

We calculated the concentrations of total ARGs in the samples as a $\log _{10}$ value of the sum of concentrations of all the tested ARGs for each sample, where one half of LOD value was used for the data analysis of ARG-negative samples [27]. We used paired t-test to compare the absolute and relative abundances of total ARGs, individual ARGs, intI1, and total bacterial 16S rRNA across different treatment stages by using Microsoft Excel 2016 (Redmond, WA, USA). We calculated $\log _{10}$ reduction value (LRV) as the $\log _{10}$ difference of ARG concentrations before and after a treatment process. Datasets with ARGs and intI1 concentrations below LOD values before a treatment process were not included for determining LRVs. We conducted Kendall Tau-b correlation coefficient test with R statistical software, version 3.6.1, by using RStudio to determine the relationship among the concentrations of intI1, total bacterial 16S rRNA, and individual and total ARGs. A $p$ value of less than 0.05 was considered significant.

\section{Results and Discussion}

\subsection{Occurrence of Total Bacterial $16 S$ rRNA, IntI1, and ARGs in Wastewater Samples}

Table 1 shows the positive ratios and mean concentrations of total bacterial 16S rRNA, ARGs, and intI1 in the wastewater samples of WWTPs. Total bacterial 16S rRNA was detected in all the samples, whereas mecA was not detected in any of the wastewater samples. Individual ARGs were detected in 100\% and 67-92\% of influent samples of Plants A and B, respectively. Although 7-9 (64-82\%) samples were found to be positive for at least one of the tested ARGs in the effluent of Plant A, only 6 $(50 \%)$ samples were tested positive for tet $A$ in the final effluent of Plant $B$. The mean concentrations of intI1 were $4.5 \pm 0.6$ and $2.4 \pm 1.1 \log _{10}$ copies/mL in the final effluents of Plants $\mathrm{A}$ and $\mathrm{B}$, respectively. 
Table 1. Detection of total bacterial $16 \mathrm{~S}$ rRNA, ARGs, and intI1 in wastewater samples.

\begin{tabular}{|c|c|c|c|c|c|c|c|}
\hline \multirow{2}{*}{ WWTP } & \multirow{2}{*}{ Tested Gene } & \multicolumn{2}{|c|}{ Influent } & \multicolumn{2}{|c|}{ Secondary Effluent } & \multicolumn{2}{|c|}{ Final Effluent } \\
\hline & & $\begin{array}{l}\text { No. of Positive } \\
\text { Samples (\%) }\end{array}$ & $\begin{array}{c}\text { Conc. (Mean } \pm \text { SD) } \\
\left(\log _{10} \text { copies } / \mathrm{mL}\right)\end{array}$ & $\begin{array}{l}\text { No. of Positive } \\
\text { Samples (\%) }\end{array}$ & $\begin{array}{l}\text { Conc. (mean } \pm \text { SD) } \\
\left(\log _{10} \text { copies } / \mathrm{mL}\right)\end{array}$ & $\begin{array}{l}\text { No. of Positive } \\
\text { Samples (\%) }\end{array}$ & $\begin{array}{c}\text { Conc. (Mean } \pm \text { SD) } \\
\left(\log _{10} \text { copies } / \mathrm{mL}\right)\end{array}$ \\
\hline \multirow[t]{6}{*}{ Plant A } & $\begin{array}{c}\text { Total bacterial } \\
16 \mathrm{~S} \text { rRNA }\end{array}$ & $11(100)$ & $7.9 \pm 0.7$ & $11(100)$ & $7.8 \pm 0.3$ & $11(100)$ & $7.4 \pm 0.4$ \\
\hline & tet $A$ & $11(100)$ & $5.3 \pm 1.0$ & $11(100)$ & $4.4 \pm 0.4$ & $9(82)$ & $3.3 \pm 1.5$ \\
\hline & ermF & $11(100)$ & $4.8 \pm 1.1$ & $11(100)$ & $4.7 \pm 1.8$ & $7(64)$ & $3.3 \pm 1.9$ \\
\hline & $b l a_{\mathrm{TEM}}$ & $11(100)$ & $5.3 \pm 0.8$ & $11(100)$ & $4.9 \pm 1.3$ & $8(73)$ & $3.6 \pm 1.6$ \\
\hline & mecA & $0(0)$ & NA & $0(0)$ & NA & $0(0)$ & NA \\
\hline & intI1 & $11(100)$ & $5.5 \pm 0.8$ & $11(100)$ & $5.0 \pm 0.4$ & $11(100)$ & $4.5 \pm 0.6$ \\
\hline \multirow[t]{6}{*}{ Plant B } & $\begin{array}{c}\text { Total bacterial } \\
16 \mathrm{~S} \text { rRNA }\end{array}$ & $12(100)$ & $7.6 \pm 1.4$ & $12(100)$ & $7.1 \pm 0.7$ & $12(100)$ & $5.7 \pm 1.0$ \\
\hline & tet $A$ & $11(92)$ & $4.6 \pm 1.5$ & $12(100)$ & $3.6 \pm 0.7$ & $6(50)$ & $1.4 \pm 1.2$ \\
\hline & ermF & $8(67)$ & $4.0 \pm 2.5$ & $7(58)$ & $2.6 \pm 1.2$ & $0(0)$ & NA \\
\hline & $b l a_{\mathrm{TEM}}$ & $9(75)$ & $4.5 \pm 2.0$ & $5(42)$ & $3.1 \pm 2.0$ & $0(0)$ & NA \\
\hline & $m e c A$ & $0(0)$ & NA & $0(0)$ & NA & $0(0)$ & NA \\
\hline & intI1 & $12(100)$ & $5.0 \pm 1.3$ & $12(100)$ & $4.1 \pm 0.9$ & $7(58)$ & $2.4 \pm 1.1$ \\
\hline
\end{tabular}

NA: not applicable.

The presence of ARGs and intI1 across different treatment processes of WWTPs has been widely observed in research works $[28,29]$. The high prevalence of ARGs in raw sewage can be attributed to the prolonged use of antibiotics, to which these ARGs confer resistance, in the study area [30]. Despite the failure to detect mecA in our samples, other studies conducted in Taiwan [31] and Sweden [32] have reported the presence of $m e c A$ in wastewater. As discussed in a previous study [27], the mecA gene is present in chromosomal DNA instead of plasmids, further resulting in a limited range of host bacteria, which makes it difficult to be detected in WWTPs covering smaller areas with less population. In some sample sets, the concentrations of ARGs and intI1 were greater in the secondary and final effluents as compared to the influent. Positive selection of ARB has been shown to occur in the biological treatment processes [33]. Biofilm formation in wastewater, likelihood of cell-to-cell contact due to high bacterial density, and the availability of abundant nutrients promote ARG exchange [34], which might explain the increase in ARGs and intI1 in secondary effluent.

\subsection{Reduction of ARGs and IntI1 at WWTPS}

As shown in Table 2, both the physical-biological treatment and chlorination processes achieved the reduction of total bacterial $16 \mathrm{~S}$ rRNA, individual and total ARGs, and intI1. After undergoing physical-biological treatment, only tet $A$ concentrations were significantly reduced in Plant A among the tested ARGs (t-test, $p<0.05$ ), whereas none of ARG or intI1 concentrations were significantly reduced in Plant B (t-test, $p>0.05$ ). Concentrations of all the tested total bacterial $16 \mathrm{~S}$ rRNA, ARGs, int11, and total ARGs decreased significantly (t-test, $p<0.05$ ) after chlorination at both Plants A and B. The lower concentrations of total coliforms in the final effluents of Plant B and BOD and TSS concentrations of less than $7 \mathrm{mg} / \mathrm{L}$ in final effluents of Plant A [20] suggest compliance to the effluent standards and the proper functioning of the WWTP.

Significant reductions of individual ARGs, total bacterial 16S rRNA, and intI1 (t-test, $p<0.05$ ) at conventional WWTPs with similar LRVs have been reported in previous studies conducted elsewhere $[7,35,36]$. The comparison of individual concentrations of ARGs, intI1, total bacterial $16 \mathrm{~S}$ rRNA, and total ARGs in influent, secondary effluent, and final effluent samples revealed disinfection with chlorination as the critical step in the degradation of ARGs. Because the concentration of bacterial DNA was performed by filtering through a $0.22-\mu \mathrm{m}$ pore size membrane, the ARGs are likely to be intracellular ARGs. Chlorine as an oxidant destroys nucleic acid and cell membrane of bacteria, thereby resulting in ARG degradation, and it is the most common form of globally used disinfectant [37]. Results have shown that the removal of ARGs is affected by ammonia nitrogen concentration in wastewater, and a maximum removal of ARGs (up to $1.49 \log _{10}$ removal) can be achieved at a free chlorine dosage of $30 \mathrm{mg} / \mathrm{L}$ with a 30-min contact time [38]. A limitation of our study was that we did not measure the residual chlorine and ammonia nitrogen in wastewater samples. The correlation analysis of individual and total ARGs with residual chlorine would have further explained the effect of chlorination on ARGs. 
Table 2. LRVs of total bacterial 16S rRNA, ARGs, intI1, total coliforms, and E. coli at WWTPs.

\begin{tabular}{|c|c|c|c|c|}
\hline \multirow{2}{*}{ WWTP } & \multirow{2}{*}{ Tested Gene } & \multicolumn{3}{|c|}{ LRV (Mean \pm SD) (No. of Months Used for Calculation) } \\
\hline & & Physical-Biological Treatment & Chlorination & Whole Process \\
\hline \multirow{6}{*}{ Plant A } & Total bacterial 16S rRNA & $0.1 \pm 0.6(11)$ & $0.4 \pm 0.5 *(11)$ & $0.6 \pm 0.8 *(11)$ \\
\hline & $\operatorname{tet} A$ & $0.9 \pm 1.1 *(11)$ & $1.1 \pm 1.6 \#(11)$ & $2.0 \pm 2.1 \#^{*}(11)$ \\
\hline & ermF & $0.1 \pm 1.9(11)$ & $1.3 \pm 1.7 \#^{*}(11)$ & $1.4 \pm 2.5 \#^{*}(11)$ \\
\hline & $b l a_{\mathrm{TEM}}$ & $0.4 \pm 1.5(11)$ & $1.3 \pm 1.6 \#^{*}(11)$ & $1.7 \pm 1.8 \#^{*}(11)$ \\
\hline & Total ARGs & $0.2 \pm 1.6(11)$ & $1.2 \pm 1.6 \#^{*}(11)$ & $1.4 \pm 2.2 \#^{*}(11)$ \\
\hline & intI1 & $0.5 \pm 0.8(11)$ & $0.5 \pm 0.6 *(11)$ & $1.1 \pm 1.1 *(11)$ \\
\hline \multirow{8}{*}{ Plant B } & Total bacterial $16 \mathrm{~S}$ rRNA & $0.5 \pm 1.6(12)$ & $1.4 \pm 1.0 *(12)$ & $1.9 \pm 1.6 *(12)$ \\
\hline & tet $A$ & $1.3 \pm 1.2(11)$ & $2.2 \pm 2.1 \#^{*}(12)$ & $3.6 \pm 1.2 \#^{*}(11)$ \\
\hline & ermF & $2.3 \pm 2.6 \#(8)$ & $2.1 \pm 0.7 \#^{*}(7)$ & $3.9 \pm 2.1 \#^{*}(8)$ \\
\hline & $b l a_{\mathrm{TEM}}$ & $2.7 \pm 2.3 \#(9)$ & $4.1 \pm 0.6 \#^{*}(5)$ & $4.2 \pm 0.9 \#^{*}(9)$ \\
\hline & Total ARGs & $1.5 \pm 2.5$ & $1.9 \pm 1.1 \#^{*}(12)$ & $3.5 \pm 1.8 \#^{*}(11)$ \\
\hline & intI1 & $1.2 \pm 1.2(11)$ & $1.7 \pm 1.0 \#^{*}(12)$ & $2.9 \pm 1.1 \#^{*}(11)$ \\
\hline & Total coliforms & $0.9 \pm 0.1(12)$ & $1.6 \pm 1.1 \#^{*}(12)$ & $1.7 \pm 1.1 \#^{*}(12)$ \\
\hline & E. coli & $0.7 \pm 0.6 *(12)$ & $1.9 \pm 0.9 \#^{*}(12)$ & $2.6 \pm 1.1 \#^{*}(12)$ \\
\hline
\end{tabular}

SD, standard deviation; \# Samples with substituted values and the reduction may be greater than calculated;

* significant reduction $(p$ value $<0.05)$.

\subsection{Relative Abundance of ARGs in Influent and Final Effluent Samples of WWTPs}

Figure 2 shows the relative abundance of intI1, individual and total ARGs to total bacterial $16 \mathrm{~S}$ rRNA. A significant decrease in the relative abundance of intI1, tet $A$, and $b l a_{\text {TEM }}$ was observed in Plant A ( $t$-test, $p<0.05)$, whereas all tested genes, except for ermF, were reduced significantly ( $t$-test, $p<0.05)$ in Plant B. As such, it appeared that these WWTPs reduced bacteria, intI1, and certain ARGs at comparable rates. There are conflicting research results on whether WWTPs reduce or increase or bring no change in the relative abundance of ARGs [13,39-41]. Although all treatment methods reduce the concentrations of ARGs, changes in the relative abundance in ARGs could depend on the employed treatment technology. In China, a study comparing various advanced secondary treatment suggested the prioritization of constructed wetland as a better alternative in treating ARGs because it had an advantage in reducing the relative abundance of ARGs [42].

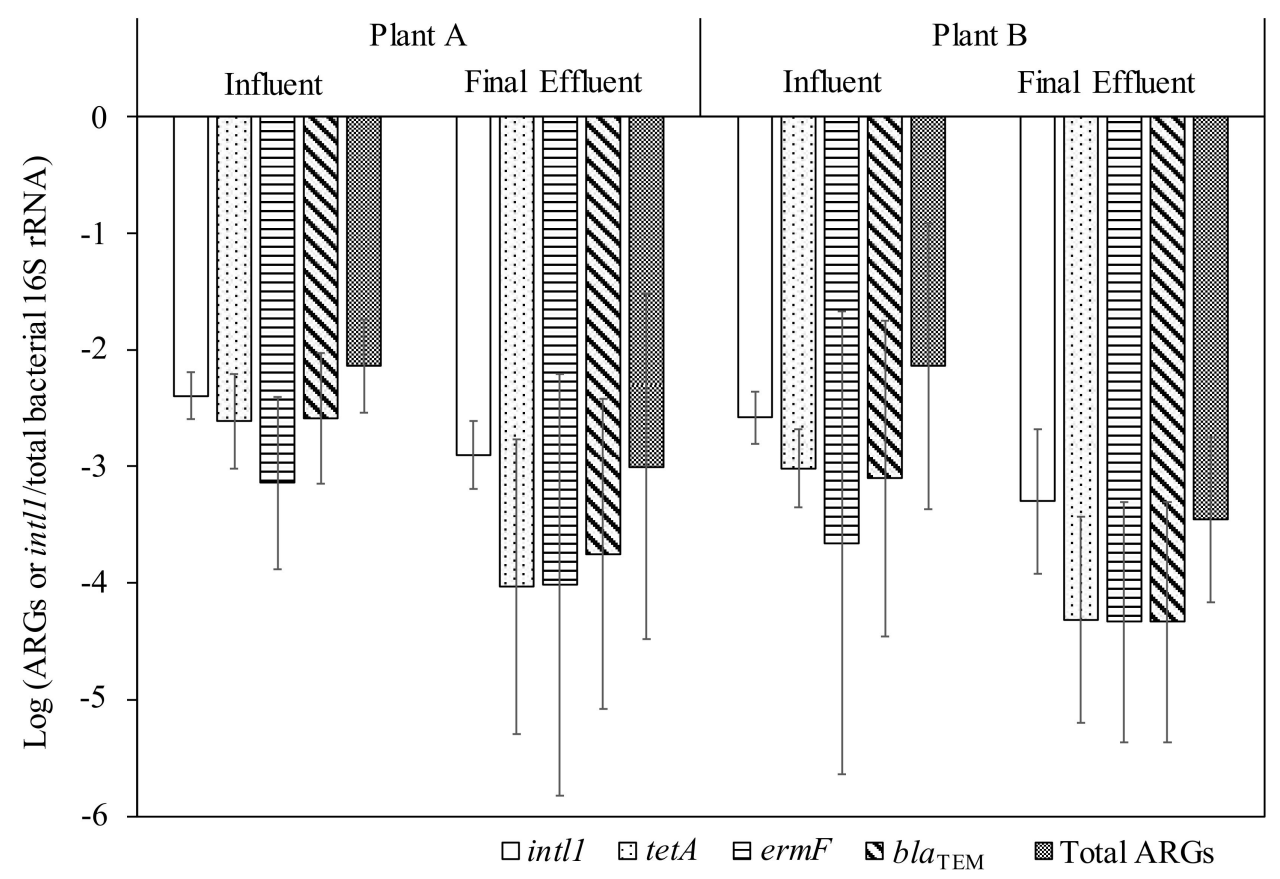

Figure 2. Concentrations of total bacteria, ARGs, and intI1 in the wastewater samples. 
Despite the significant reduction of ARGs and intI1 in final effluent, two WWTPs on an average still released $3.3 \pm 1.7$ and $3.4 \pm 1.4 \log _{10}$ copies/mL of total ARGs and intI1, respectively, into the Mississippi River. We did not evaluate the effects of discharging effluents containing ARGs and intI1 in the Mississippi River in this study. The presence of ARGs and intI1 increases the probability of horizontal transfer of ARGs into potential pathogenic bacteria, eventually leading to an increased exposure to ARB. Future research works should focus on developing a quantitative microbial risk assessment framework to assess the risk arising from exposure to water bodies via water reuse or recreation purposes.

\subsection{Correlation of Individual and Total ARGs with IntI1}

As shown in Table 3, the individual and total ARGs shared a significant positive correlation with intI1 $(0.48-0.90, p<0.05)$ in all the wastewater samples. The persistence of intI1 across all treatment processes and consistent correlation to ARGs suggest the use of intI1 as an indicator of the presence of ARGs in wastewater [19]. E. coli and total coliforms have been shown to correlate with ARGs in an aquatic environment [3]. However, we did not perform the correlation analysis between E. coli and ARGs in this study because of the absence of viable $E$. coli and total coliforms in majority of the final effluent samples. Bacteria are able to acquire ARGs not only through conjugation but also through transformation, involving the uptake of extracellular DNA, and transduction, involving the transfer of ARGs via bacteriophages [43]. Thus, the spread of antibiotic resistance through extracellular DNA and bacteriophages harboring ARGs can be neglected by using viable bacteria as a water quality parameter.

Table 3. Kendall tau $(\tau)$ correlation coefficient between intI1 and ARGs.

\begin{tabular}{ccccc}
\hline Samples $(\mathbf{n = 2 3 )}$ & bla TEM & tet $A$ & ermF & Total ARGs \\
\hline Influent & $0.60^{*}$ & $0.90^{*}$ & $0.65^{*}$ & $0.79 *$ \\
Secondary effluent & $0.48^{*}$ & $0.78^{*}$ & $0.64^{*}$ & $0.60 *$ \\
Final effluent & $0.61^{*}$ & $0.64^{*}$ & $0.53^{*}$ & $0.59 *$ \\
\hline \multicolumn{5}{c}{$p<0.05}$.
\end{tabular}

\section{Conclusions}

This study demonstrated the ability of WWTPs to significantly reduce ARGs and intI1 in wastewater. Chlorination was adjudged as a critical step in the reduction of ARGs; however, the WWTPs were still releasing $3.3 \pm 1.7 \log _{10}$ copies/mL of total ARGs studied in effluents. Correlation analysis and the ability of intI1 to persist through the treatment processes recommend the use of intI1 as a marker of ARGs in effluents to monitor the spread of antibiotic resistance in effluents. Overall, our study suggests that conventional WWTPs using chlorination do not favor the proliferation of ARB and ARGs during wastewater treatment.

Author Contributions: Conceptualization, O.T., S.P.S. and E.H.; methodology, S.S., J.P.B. and S.P.S.; validation, J.P.B., S.P.S. and E.H.; formal analysis, O.T.; visualization, O.T. and E.H.; writing-original draft preparation, O.T.; writing-review and editing, S.S., J.P.B., S.P.S. and E.H.; supervision, S.P.S., E.H. All authors have read and agreed to the published version of the manuscript.

Funding: This research received no external funding.

Acknowledgments: We would like to thank the local authorities of the wastewater treatment plants for providing the samples and necessary information for this study.

Conflicts of Interest: The authors declare no conflict of interest.

\section{References}

1. Van Goethem, M.W.; Pierneef, R.; Bezuidt, O.K.I.; Van De Peer, Y.; Cowan, D.A.; Makhalanyane, T.P. A reservoir of "historical" antibiotic resistance genes in remote pristine Antarctic soils. Microbiome 2018, 6, 40. [CrossRef] 
2. Karkman, A.; Pärnänen, K.; Larsson, D.G.J. Fecal pollution can explain antibiotic resistance gene abundances in anthropogenically impacted environments. Nat. Commun. 2019, 10, 80. [CrossRef]

3. Thakali, O.; Tandukar, S.; Brooks, J.P.; Sherchan, S.P.; Sherchand, J.B.; Haramoto, E. The Occurrence of Antibiotic Resistance Genes in an Urban River in Nepal. Water 2020, 12, 450. [CrossRef]

4. Levy, S.; Marshall, B. Antibacterial resistance worldwide: Causes, challenges and responses. Nat. Med. 2004, 10, S122-S129. [CrossRef]

5. Rizzo, L.; Manaia, C.; Merlin, C.; Schwartz, T.; Dagot, C.; Ploy, M.C.; Michael, I.; Fatta-Kassinos, D. Urban wastewater treatment plants as hotspots for antibiotic resistant bacteria and genes spread into the environment: A review. Sci. Total Environ. 2013, 447, 345-360. [CrossRef]

6. McKinney, C.W.; Pruden, A. Ultraviolet disinfection of antibiotic resistant bacteria and their antibiotic resistance genes in water and wastewater. Environ. Sci. Technol. 2012, 46, 13393-13400. [CrossRef]

7. Gao, P.; Munir, M.; Xagoraraki, I. Correlation of tetracycline and sulfonamide antibiotics with corresponding resistance genes and resistant bacteria in a conventional municipal wastewater treatment plant. Sci. Total Environ. 2012, 421-422, 173-183. [CrossRef]

8. Munir, M.; Wong, K.; Xagoraraki, I. Release of antibiotic resistant bacteria and genes in the effluent and biosolids of five wastewater utilities in Michigan. Water Res. 2011, 45, 681-693. [CrossRef]

9. Lamori, J.G.; Xue, J.; Rachmadi, A.T.; Lopez, G.U.; Kitajima, M.; Gerba, C.P.; Pepper, I.L.; Brooks, J.P.; Sherchan, S. Removal of fecal indicator bacteria and antibiotic resistant genes in constructed wetlands. Environ. Sci. Pollut. Res. 2019, 26, 10188-10197. [CrossRef]

10. Rafraf, I.D.; Lekunberri, I.; Sànchez-Melsió, A.; Aouni, M.; Borrego, C.M.; Balcázar, J.L. Abundance of antibiotic resistance genes in five municipal wastewater treatment plants in the Monastir Governorate, Tunisia. Environ. Pollut. 2016, 219, 353-358. [CrossRef]

11. Amarasiri, M.; Sano, D.; Suzuki, S. Understanding human health risks caused by antibiotic resistant bacteria (ARB) and antibiotic resistance genes (ARG) in water environments: Current knowledge and questions to be answered. Crit. Rev. Environ. Sci. Technol. 2019. [CrossRef]

12. Christgen, B.; Yang, Y.; Ahammad, S.Z.; Li, B.; Rodriquez, D.C.; Zhang, T.; Graham, D.W. Metagenomics shows that low-energy anaerobic-aerobic treatment reactors reduce antibiotic resistance gene levels from domestic wastewater. Environ. Sci. Technol. 2015, 49, 2577-2584. [CrossRef]

13. Mao, D.; Yu, S.; Rysz, M.; Luo, Y.; Yang, F.; Li, F.; Hou, J.; Mu, Q.; Alvarez, P.J.J. Prevalence and proliferation of antibiotic resistance genes in two municipal wastewater treatment plants. Water Res. 2015, 85, 458-466. [CrossRef]

14. Hong, P.Y.; Julian, T.R.; Pype, M.L.; Jiang, S.C.; Nelson, K.L.; Graham, D.; Pruden, A.; Manaia, C.M. Reusing treated wastewater: Consideration of the safety aspects associated with antibiotic-resistant bacteria and antibiotic resistance genes. Water 2018, 10, 244. [CrossRef]

15. Hong, P.Y.; Al-Jassim, N.; Ansari, M.I.; Mackie, R.I. Environmental and public health implications of water reuse: Antibiotics, antibiotic resistant bacteria, and antibiotic resistance genes. Antibiotics 2013, 2, 367-399. [CrossRef]

16. Volkmann, H.; Schwartz, T.; Bischoff, P.; Kirchen, S.; Obst, U. Detection of clinically relevant antibiotic-resistance genes in municipal wastewater using real-time PCR (TaqMan). J. Microbiol. Methods 2004, 56, 277-286. [CrossRef]

17. Szczepanowski, R.; Linke, B.; Krahn, I.; Gartemann, K.H.; Gützkow, T.; Eichler, W.; Pühler, A.; Schlüter, A. Detection of 140 clinically relevant antibiotic-resistance genes in the plasmid metagenome of wastewater treatment plant bacteria showing reduced susceptibility to selected antibiotics. Microbiology 2009, 155, 2306-2319. [CrossRef]

18. Barraud, O.; Baclet, M.C.; Denis, F.; Ploy, M.C. Quantitative multiplex real-time PCR for detecting class 1, 2 and 3 integrons. J. Antimicrob. Chemother. 2010, 65, 1642-1645. [CrossRef]

19. Narciso-Da-Rocha, C.; Varela, A.R.; Schwartz, T.; Nunes, O.C.; Manaia, C.M. bla $a_{\mathrm{TEM}}$ and vanA as indicator genes of antibiotic resistance contamination in a hospital-urban wastewater treatment plant system. J. Glob. Antimicrob. Resist. 2014, 2, 309-315. [CrossRef]

20. Tandukar, S.; Sherchan, S.P.; Haramoto, E. Applicability of crAssphage, pepper mild mottle virus, and tobacco mosaic virus as indicators of reduction of enteric viruses during wastewater treatment. Sci. Rep. 2020, 10, 3616. [CrossRef] 
21. APHA/AWWA/WEF. Standard Methods for the Examination of Water and Wastewater, 20th ed.; Clesceri, L.S., Greenberg, A.E., Eaton, A.D., Eds.; American Public Health Association, American Water Works Association, Water Environment Federation: Washington, DC, USA, 1998.

22. Nadkarni, M.A.; Martin, F.E.; Jacques, N.A.; Hunter, N. Determination of bacterial load by real-time PCR using a broad-range (universal) probe and primers set. Microbiology 2002, 148, 257-266. [CrossRef]

23. Fan, W.; Hamilton, T.; Webster-Sesay, S.; Nikolich, M.P.; Lindler, L.E. Multiplex real-time SYBR Green I PCR assay for detection of tetracycline efflux genes of gram-negative bacteria. Mol. Cell Probes 2007, 21, 245-256. [CrossRef]

24. Lachmayr, K.L.; Cavanaugh, C.M.; Kerkhof, L.J.; DiRienzo, A.G.; Ford, T.E. Quantifying nonspecific tem $\beta$-lactamase (blatem) genes in a wastewater stream. Appl. Environ. Microbiol. 2009, 75, 203-211. [CrossRef]

25. Sabet, N.S.; Subramaniam, G.; Navaratnam, P.; Sekaran, S.D. Detection of methicillin-and aminoglycoside-resistant genes and simultaneous identification of S. aureus using triplex real-time PCR Taqman assay. J. Microbiol. Methods 2007, 68, 157-162. [CrossRef]

26. Chen, J.; Yu, Z.; Michel, F.C.; Wittum, T.; Morrison, M. Development and application of real-time PCR assays for quantification of erm genes conferring resistance to macrolides-lincosamides-streptogramin B in livestock manure and manure management systems. Appl. Environ. Microbiol. 2007, 73, 4407-4416. [CrossRef]

27. McConnell, M.M.; Truelstrup Hansen, L.; Jamieson, R.C.; Neudorf, K.D.; Yost, C.K.; Tong, A. Removal of antibiotic resistance genes in two tertiary level municipal wastewater treatment plants. Sci. Total Environ. 2018, 643, 292-300. [CrossRef]

28. Schmitz, B.W.; Innes, G.K.; Xue, J.; Gerba, C.P.; Pepper, I.L.; Sherchan, S. Reduction of erythromycin resistance gene erm (F) and class 1 integron-integrase genes in wastewater by Bardenpho treatment. Water Environ. Res. 2020, 1-9. [CrossRef]

29. Wang, J.; Mao, D.; Mu, Q.; Luo, Y. Fate and proliferation of typical antibiotic resistance genes in five full-scale pharmaceutical wastewater treatment plants. Sci. Total Environ. 2015, 526, 366-373. [CrossRef]

30. Davies, J.; Davies, D. Origins and Evolution of Antibiotic Resistance. Microbiol. Mol. Biol. Rev. 2010, 74, 417-433. [CrossRef]

31. Wan, M.T.; Chou, C.C. Spreading of $\beta$-lactam resistance gene (mecA) and methicillin-resistant Staphylococcus aureus through municipal and swine slaughterhouse wastewaters. Water Res. 2014, 64, 288-295. [CrossRef]

32. Börjesson, S.; Melin, S.; Matussek, A.; Lindgren, P.E. A seasonal study of the mecA gene and Staphylococcus aureus including methicillin-resistant $S$. aureus in a municipal wastewater treatment plant. Water Res. 2009, 43, 925-932. [CrossRef]

33. Da Silva, M.F.; Tiago, I.; Veríssimo, A.; Boaventura, R.A.; Nunes, O.C.; Manaia, C.M. Antibiotic resistance of enterococci and related bacteria in an urban wastewater treatment plant. FEMS Microbiol. Ecol. 2006, 55, 322-329. [CrossRef]

34. Sørensen, S.J.; Bailey, M.; Hansen, L.H.; Kroer, N.; Wuertz, S. Studying plasmid horizontal transfer in situ: A critical review. Nat. Rev. Microbiol. 2005, 3, 700-710. [CrossRef]

35. Yang, Y.; Li, B.; Zou, S.; Fang, H.H.P.; Zhang, T. Fate of antibiotic resistance genes in sewage treatment plant revealed by metagenomic approach. Water Res. 2014, 62, 97-106. [CrossRef]

36. Wen, Q.; Yang, L.; Duan, R.; Chen, Z. Monitoring and evaluation of antibiotic resistance genes in four municipal wastewater treatment plants in Harbin, Northeast China. Environ. Pollut. 2016, 212, 34-40. [CrossRef]

37. Anastasi, E.M.; Wohlsen, T.D.; Stratton, H.M.; Katouli, M. Survival of Escherichia coli in two sewage treatment plants using UV irradiation and chlorination for disinfection. Water Res. 2013, 47, 6670-6679. [CrossRef]

38. Zhang, Y.; Zhuang, Y.; Geng, J.; Ren, H.; Zhang, Y.; Ding, L.; Xu, K. Inactivation of antibiotic resistance genes in municipal wastewater effluent by chlorination and sequential UV/chlorination disinfection. Sci. Total Environ. 2015, 512-513, 125-132. [CrossRef]

39. Bengtsson-Palme, J.; Hammarén, R.; Pal, C.; Östman, M.; Björlenius, B.; Flach, C.F.; Fick, J.; Kristiansson, E.; Tysklind, M.; Larsson, D.G.J. Elucidating selection processes for antibiotic resistance in sewage treatment plants using metagenomics. Sci. Total Environ. 2016, 572, 697-712. [CrossRef]

40. Di Cesare, A.; Eckert, E.M.; D’Urso, S.; Bertoni, R.; Gillan, D.C.; Wattiez, R.; Corno, G. Co-occurrence of integrase 1 , antibiotic and heavy metal resistance genes in municipal wastewater treatment plants. Water Res. 2016, 94, 208-214. [CrossRef] 
41. Lin, W.; Zhang, M.; Zhang, S.; Yu, X. Can chlorination co-select antibiotic-resistance genes? Chemosphere 2016, 156, 412-419. [CrossRef]

42. Chen, H.; Zhang, M. Effects of advanced treatment systems on the removal of antibiotic resistance genes in wastewater treatment plants from Hangzhou, China. Environ. Sci. Technol. 2013, 47, 8157-8163. [CrossRef]

43. Giedraitienè, A.; Vitkauskienè, A.; Naginienė, R.; Pavilonis, A. Antibiotic resistance mechanisms of clinically important bacteria. Medicina (Kaunas) 2011, 47, 37-146. [CrossRef]

C 2020 by the authors. Licensee MDPI, Basel, Switzerland. This article is an open access article distributed under the terms and conditions of the Creative Commons Attribution (CC BY) license (http://creativecommons.org/licenses/by/4.0/). 